\title{
WATER DEFICIT ENSURES THE PHOTOCHEMICAL EFFICIENCY OF Copaifera langsdorffii Desf ${ }^{1}$
}

\author{
Angélica Lino Rodrigues², Liane Lima ${ }^{3}$, Thayssa Rabelo Schley ${ }^{4}$ and Luiz Fernando Rolim de Almeida ${ }^{2 *}$
}

${ }^{1}$ Received on 01.06.2016 accepted for publication on 29.03.2017.

${ }^{2}$ Universidade Estadual Paulista Júlio de Mesquita Filho, Programa de Pós-Graduação em Ciências Biológicas, Botucatu, São Paulo, Brasil.E-mail: <angelicarodrigues.bio@gmail.com> and <luizfernando@ibb.unesp.br>.

${ }^{3}$ Instituto Nacional de Pesquisas da Amazônia, Mestrado em Ciências Biológicas (Botânica), Amazônia, Brasil. E-mail: $<$ lianelimaa@gmail.com>.

${ }^{4}$ Universidade Estadual Paulista Júlio de Mesquita Filho, Mestrado em Botânica, Botucatu, São Paulo, Brasil. E-mail: <schley.thayssa@gmail.com>.

*Corresponding author.

ABSTRACT - The intensity and frequency of drought periods has increased according to climate change predictions. The fast overcome and recovery are important adaptive features for plant species found in regions presenting water shortage periods. Copaifera langsdorffii is a neotropical species that has developed leaves presenting physiological mechanisms and morphological adaptations that allow its survival under seasonal water stress. We aimed in this work to observe substantial physiological responses for water saving and damage representative to the photochemical reaction after exposed plants to water stress and to subsequent recovery. We found in plants mechanisms to control water loss through the lower stomatal conductance, even after rehydration. It goes against the rapid recovery of leaves, indicated by the relative water content values restored to previously unstressed plants. Stomatal conductance was the only variable presenting high plasticity index. In photochemical activity, the species presented higher photochemical quenching, electron transport rate and effective quantum yield of photosystem II when they were subjected to rehydration after water stress period. Our results suggest that $\boldsymbol{C}$. langsdorffii presented rapid rehydration and higher photochemical efficiency even after water restriction. These data demonstrate that this species can be used as a model for physiological studies due to the adjustment developed in response to different environmental schemes.

Keywords: Chlorophyll fluorescence; Water relations; Photosystem II.

\section{DÉFICIT HÍDRICO ASSEGURA A EFICIÊNCIA FOTOQUÍMICA DE Copaifera langsdorffii Desf}

\begin{abstract}
RESUMO - A intensidade e a frequência dos periodos de seca aumentaram de acordo com as predições de mudanças climáticas. A superação e rápida recuperação são características adaptativas importantes para espécies de plantas encontradas em regiões que apresentam periodos de falta d'água. Copaifera langsdorffii é uma espécie neotropical que desenvolveu folhas com adaptações morfológicas e mecanismos fisiológicos que permitem a sobrevivência em ambientes com estresse hídrico sazonal. O objetivo deste trabalho foi observar as respostas fisiológicas substanciais para a economia de água e possiveis danos representativos à reação fotoquímica depois de expor as plantas ao estresse hídrico e posterior reidratação. Mesmo após a reidratação, as plantas apresentaram mecanismos para controlar a perda de água através da menor condutância estomática. A rápida reidratação das folhas foi indicada pelos valores de conteúdo relativo de água semelhante às folhas não estressadas. A condutância estomática foi à única variável que apresentou alto índice de plasticidade. Na atividade fotoquímica, a espécie apresentou maior dissipação fotoquímica, taxa de transporte de elétrons e rendimento quântico efetivo do fotossistema II, quando submetidas à reidratação após o período de estresse hídrico. Os resultados sugerem que $\boldsymbol{C}$. langsdorffii apresentou rápida reidratação e maior eficiência fotoquímica mesmo após restrição hídrica. Mostrando que esta espécie pode ser utilizada como modelo em estudos fisiológicos devido ao seu ajuste desenvolvido em resposta a diferentes regimes ambientais.
\end{abstract}

Palavras-chave: Fluorescência da clorofila; Relações hídricas; Fotossistema II. 


\section{INTRODUCTION}

The accumulation of greenhouse gases in the atmosphere has changing the climate, resulting in increasing of average temperature and redistribution of global precipitation (IPCC, 2007). According to the different climate change scenarios, regions subjected to water deficit may increase the intensity and duration of drought. Hence, the overcoming of water stress periods and the recovering with the return of the rainy season are adjustment characteristics of plants often found in these dry regions (Giorgi and Lionello, 2008; Vaz et al., 2010). Once an increased frequency of drought events is predicted for the coming decades, further investigations are needed to elucidate the mechanisms of recovery from drought in the field. This could also improve predictions of ecosystem productivity and better irrigation systems.

The effects of drought are highly variable depending on length, speed of stress imposition, and stage of plant development (Ferreira et al., 2015). Many species show morphological, physiological and biochemical mechanisms to overcome an inadequate supply of water, such as changes in the pattern of growth and development of vegetative organs, changes in stomatal conductance, adjusting osmotic potential of tissues and production of secondary metabolic substances (Smirnoff, 1993; Chaves et al., 2002; Gaspar et al., 2002; Carvalho, 2008).

Water deficit in plants leads to changes in photosynthetic rate. It can be caused by stomatal closure, or by damages in photosynthetic apparatus because of impaired photochemical reactions ( $\mathrm{Wu}$ and Bao, 2011). Drought stress may decrease the electron transport requirement for photosynthesis and reduce PSII photochemical activity, which results in an overexcitation and photoinhibition damage to PSII reaction centers (Meng et al., 2016). The damage of the photosynthetic apparatus makes plants more susceptible to other environmental stresses. It affects plant growth and establishment (Anjos et al., 2015). The species that do not show damage to photosynthetic apparatus and exposes higher phenotypic plasticity can explain the establishment in a wide range of different environmental conditions (Barros et al., 2012).

Copaifera langsdorffii Desf., Fabaceae, subfamily Detarioideae (LPWG, 2017) is a neo-tropical tree that grows in a wide range of seasonal environments. The seedlings present great capacity to survive under contrasting light and water availability (Carvalho, 2003), being largely tolerant to environmental conditions found in fragmented environments as in Brazilian savanna (Martins et al., 2015). The wide distribution reflects the potential plasticity displayed by the species in response to different climatic regimes, presenting morphological and anatomical differences intraspecific in their populations (Melo Júnior et al., 2012). The study of Ronquim et al. (2009) showed that C. langsdorffii should present leaf physiological mechanisms and morphological adaption and it would allow this species to overcome spatial irradiance variation and seasonal water stress in vegetation areas. The authors suggest that young $C$. langsdorffii plants survived water stress under natural conditions due to the rapid and intense biomass accumulation in their roots in early development stages. In the dry season, the plants of Brazilian savannah lose leaves relieving water stress, which results in less intense gas exchange and water saving (Dalmolin et al., 2015). During the wet season, C. langsdorffii plants maximize carbon gain with the fully developed canopy, which influences the abundant flowering and high fruit yield promoting the establishment of the species in seasonal environments (Pedroni et al., 2002). In addition, this species can be used as a model in physiological studies due to its adjustment developed in response to different environmental regimes.

This study evaluated the photochemical performance of Copaifera langsdorffii Desf. submitted to water stress and subsequent rehydration, as well as, identified the variables contributing to this photochemical efficiency. Our hypothesis is $C$. langsdorffii reveals efficient photochemical performance in response to water deficit and rehydration, due to leaf physiological mechanisms that would allow this species to overcome seasonal water stress in different vegetation areas.

\section{MATERIALS AND METHODS}

The research was conducted in the Botany Department of State University of São Paulo, Botucatu Campus, Brazil. It was performed in a greenhouse under semi-controlled conditions and relative humidity between 50 and $70 \%, 13$ hours photoperiod, maximum night and day temperatures were close to 25 and $29^{\circ} \mathrm{C}$, respectively, and maximum PPFD (photosynthetic photon flux density) $800 \mu \mathrm{mol} \mathrm{m}^{-2} \mathrm{~s}^{-1}$. 
The experiment consisted of exposing $C$. langsdorffii plants to severe water stress and rehydration conditions. Plants $35 \mathrm{~cm}$ tall were planted in 5 -L pots filled with soil from a Cerrado area. The soil was characterized as red Latosol (Oxisol), whose granulometric analysis showed mean values of 788 g. $\mathrm{kg}^{-1}$ sand, 110 g. kg-1 clay, and 102 g. $\mathrm{kg}^{-1}$ silt (sandy textural class) and field capacity of $-0.006 \mathrm{MPa}$. Plants were daily irrigated and kept at maximum storage capacity (MSC) of water until the beginning of the experiment. The MSC of water was calculated through pot weighing; plants were irrigated and the water was drained from the soil, according to the methodology described by Varone et al. (2012).

The study was divided in two treatments, with 4 replicates each. The pots of Control treatment, plants were kept at the MSC of water throughout the experiment, and those for the Water stress plants were subject to water deficit followed by rehydration. All plants were acclimated under favourable hydric conditions, for approximately 60 days. Only the water stress group was subjected to total irrigation suspension for more than 35 days during the experiment. The withholding of water for 35 days adopted in the present study was based on previous testing with $C$. langsdorffii. Stomatal conductance $\left(g_{\mathrm{s}}\right)$ values decreased to $10 \%$ of the maximum gas exchange exhibited by plants grown under favourable conditions on the 35 th day of drought. Stressed pots were rehydrated until the MSC equal to that of the Control group from the initial experiment. The physiological aspects were analysed at four times: at the end of stress period (Drought); one day of rehydration $(24 \mathrm{~h})$; and two and four days of rehydration (48 h and $96 \mathrm{~h}$ ).

Fully expanded younger leaves, from the second or third node, were selected for measurements per replicate. Stomatal conductance $\left(g_{\mathrm{s}}\right)$ measurements were done by using Leaf Porometer Model SC-1 (Decagon Devices Inc., USA). The relative water content (RWC) were analysed in fully expanded leaf removed from the second or third node per replicate. A leaf from each plant was cut in rectangles $(3 \mathrm{~cm} \times 4 \mathrm{~cm})$ and immediately weighed to obtain the fresh weight (FW). Next, the samples were placed in Petri dishes covered with filter paper, immersed in deionised water and conditioned for 24 hours, at $5{ }^{\circ} \mathrm{C}$, for rehydration, according to Elsheery and Cao (2008). After this period, the samples were weighed to obtain the turgid weight (TW); next, they were oven-dried (temperature $\mathrm{H}^{\prime \prime} 60^{\circ} \mathrm{C}$ to constant weight) to obtain the dry weight (DW). An analytical scale with $0.0001 \mathrm{~g}$ accuracy (Bel Engineering, Italy.) was used to determine the fresh, turgid and dry weights. The RWC values were obtained according to Smart and Bingham (1974), through the formula: RWC (\%) $=(\mathrm{FW}-\mathrm{DW}) /(\mathrm{TW}-\mathrm{DW}) * 100$. The physiological analyses on data about water relations were measured at midday (MD).

Chlorophyll fluorescence parameters were obtained through PAM Fluorometer - Junior (WALZ, Effeltrich, Germany). Different photochemical variables were calculated according to chlorophyll fluorescence parameters, namely: the $F_{\mathrm{M}}$ and $F_{0}$ are the maximum and minimum fluorescence of dark-adapted leaves, respectively; the maximum quantum efficiency of PSII $\left(F_{\mathrm{V}} / F_{\mathrm{M}}\right)$, the effective quantum yield of $\Phi_{\mathrm{PSII}}\left(\Phi_{\mathrm{PSII}}=\right.$ $\Delta F / F_{\mathrm{M}}$ ') measured according to Genty et al. (1989), the photochemical quenching $\left[\mathrm{qP}=\left(F_{\mathrm{M}}{ }^{\prime}-F_{\mathrm{S}}\right) /\left(F_{\mathrm{M}}\right.\right.$, $\left.\left.-F_{0}{ }^{\prime}\right)\right]$, the non-photochemical quenching $\left[\mathrm{NPQ}=\left(F_{\mathrm{M}}\right.\right.$ $\left.\left.-F_{\mathrm{M}}{ }^{\prime}\right) / F_{\mathrm{M}}{ }^{\prime}\right]$ and the electron transport rate $(\mathrm{ETR}=\Delta F /$ $F_{\mathrm{M}}{ }^{\prime} \times$ PPFD $\left.\times 0.5 \times \alpha\right)$. We used the mean value of 0.84 for leaf absorption $(\alpha)$ for green leaves (Maxwell and Johnson, 2000; Baker, 2008). The attached leaves were covered with aluminium foil and kept in the dark for approximately 30 minutes. The light curve generated in the fluorometer with eight actinic light pulses (125, $190,285,420,625,820,1150$ and $1500 \mu \mathrm{mol} \mathrm{m}^{-2} \mathrm{~s}^{-1}$ PPFD), with 10 s of intervals between the pulses, were applied. The chlorophyll fluorescence parameters and water relation variables were analysed at same time $(11: 00 \mathrm{~h})$.

Soil samples were collected and analysed on a water potential analyser under controlled temperature, WP4-T (Decagon Devices Inc., USA) to evaluate the water potential of the soil $\left(\Psi_{\mathrm{s}}\right)$. The moisture in the chamber was balanced with the water potential in the soil, which was calculated according to the soil temperature and the dew point of the air. The analysis took place immediately after the biological material collection.

The experiment was a completely random design, with 4 plants per treatment. All evaluations were performed four times. The means and calculated standard errors of mean were reported. Statistical comparisons were performed with use Student' T-test complemented by Least-significance difference (LSD) test between the means used to compare the control and the stressed treatments. Statistical significance was set at $p<0.05$. 
All the data were analysed in SigmaPlot ${ }^{\circledR}$ version 12 (Chicago Inc., USA, 2011). The plasticity indices (PIs) of different variables were calculated through the mean of treatments as PI $=(\max .-\min .) / \max ($ Valladares et al., 2000) in the current study.

\section{RESULTS}

The RWC decreased sharply while drought progressed. The data demonstrated significant difference between treatments in the last irrigation suspension day (drought) when compared with control plants, thus showing minimal hydration $(p<0.05)$. No significant difference was observed between the water stress treatment and the control even $96 \mathrm{~h}$ of rehydration (Figure 1a). The $g_{\mathrm{s}}$ showed daily significant difference $(p<0.05)$, except for the first day (Figure 1b). The $g_{\mathrm{s}}$ and RWC values decreased in the drought day of total irrigation suspension measured in the water stress treatment. Only RWC was increased $24 \mathrm{~h}$ after the rehydration when $C$. langsdorffii plants were irrigated, thus indicating the delayed response of $g_{\mathrm{s}}$ in comparison to RWC. The RWC values in the rehydrated treatments were similar to those in the control, but the $g_{\mathrm{s}}$ levels remained unchanged in the water stress treatment, even $96 \mathrm{~h}$ of rehydration (Figure 1).
The $\Psi_{\mathrm{s}}$ in the water deficit treatment was evaluated to estimate water availability in the soil during the experiment. The value of $\Psi_{\mathrm{s}}$ was $-0.005 \mathrm{MPa}$ before irrigation suspension. The $\Psi_{\mathrm{s}}$ decreased to $-1.050 \mathrm{MPa}$ on the last day of the water stress period, after the irrigation was interrupted. The $\Psi_{\mathrm{s}}$ increased to -0.100 $\mathrm{MPa}$, in the 96 hours after rehydration.

The recovery induced different responses in chlorophyll fluorescence parameters. The ETR and qP values showed significant differences between treatments $(p<0.05) 48$ h of rehydration, when ETR was $70 \%$ higher than the control (Figure $2 \mathrm{c}$ ). No significant difference between the treatments was observed in NPQ and $F_{\mathrm{V}} / F_{\mathrm{M}}$ data (Figure $2 \mathrm{a}$ and d).

The effective quantum yield $\left(\Phi_{\mathrm{PSII}}\right)$ showed a significant difference $(p<0.05) 48$ h of rehydration, concurrently with the values of ETR and qP. Whilst, the minimum fluorescence $\left(F_{0}\right)$ data showed a significant difference between treatments $(p<0.05)$ 24 hours of rehydration. Maximum fluorescence values $\left(F_{\mathrm{M}}\right)$ had no significant difference among treatments (Table 1).

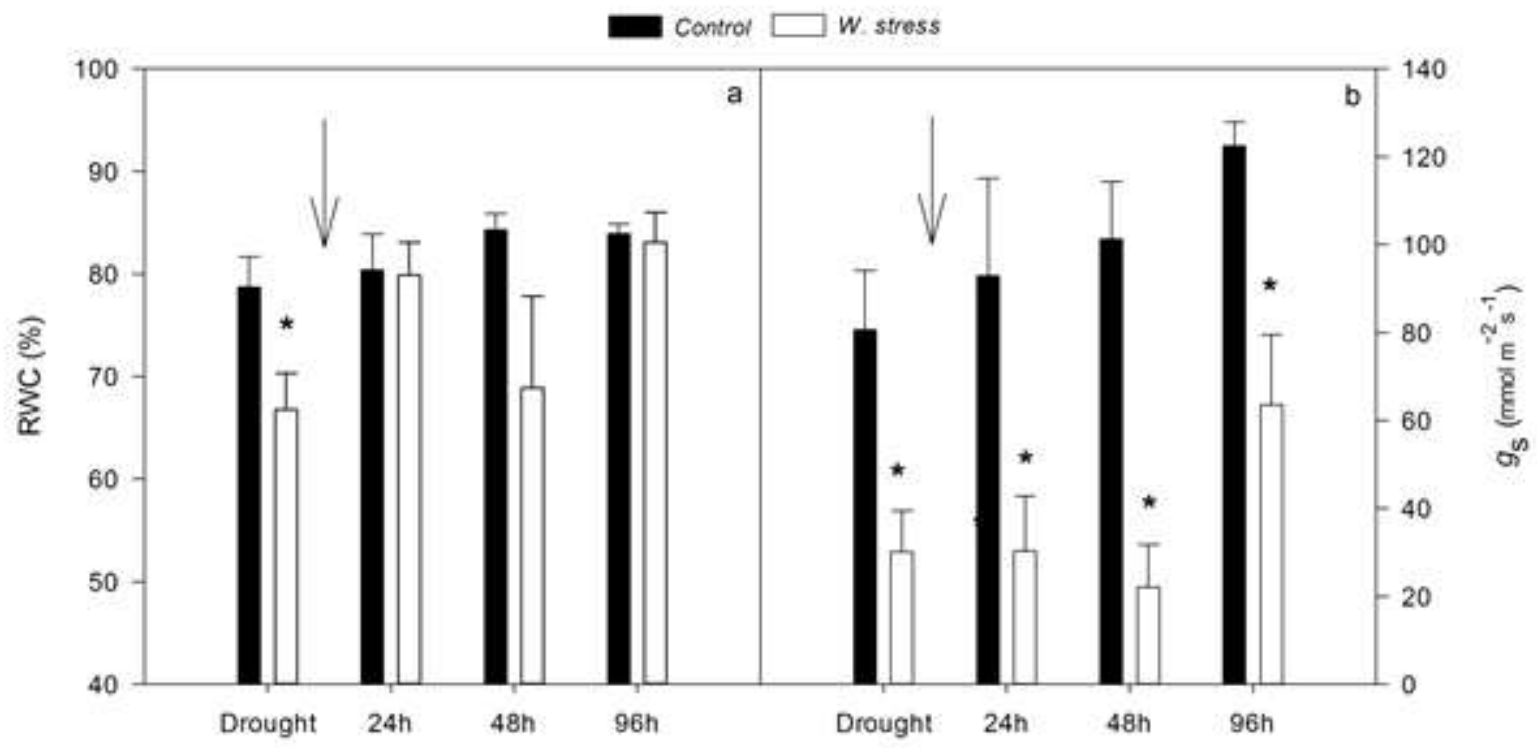

Figure 1- a Relative water content $[\mathrm{RWC}]$ and $\mathbf{b}$ Stomatal conductance $\left[g_{\mathrm{s}}\right]$ according to water availability of $C$. langsdorffii plants. Control treatment (black) - continually irrigated plants; Water stress treatment (white) - rehydrated plants after a water deficit period. The arrow indicates the rehydration. Values are mean $\pm \operatorname{SE}(n=4)$ *Indicate significant differences at $p<0.05$.

Figura 1-a Conteúdo relativo de água $[R W C]$ e b Condutância estomática $\left[g_{s}\right]$ de acordo com a disponibilidade de água em plantas de C. langsdorffii. Tratamento controle (preto) - plantas constantemente irrigadas; Tratamento de estresse hídrico (branco)-plantas reidratadas após periodo de déficit hídrico. A seta indica a reidratação. Valores referentes à média e erro padrão $(n=4)$. *Indica diferença significativa de $p<0.05$ 


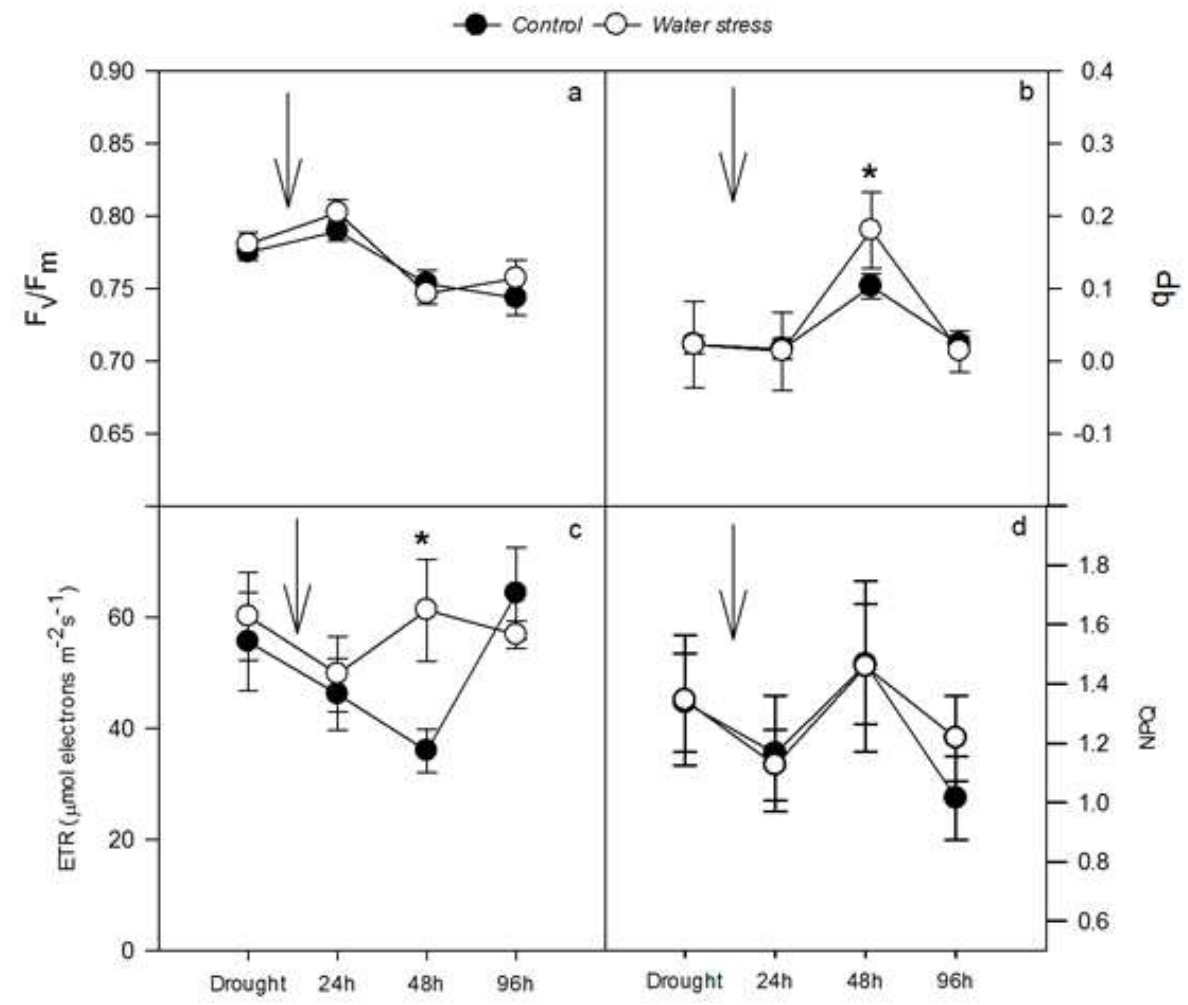

Figure 2 - Chlorophyll fluorescence parameters according to the day when the analysis was done in PPFD $1500 \mu \mathrm{mol} \mathrm{m}-$ ${ }^{2} \mathrm{~s}^{-1}$. Control treatment (black); Water stress treatment (white) rehydrated plants after a water deficit period. a. $F_{\mathrm{v}} / F_{\mathrm{M}}-$ maximum quantum efficiency of of PSII. b. qP -photochemical quenching. c. ETR - electron transport rate. d. NPQ - non-photochemical quenching. The arrow indicates the rehydration. Values are mean $\pm \operatorname{SE}(n=4)$. *Indicate significant differences at $p<0.05$.

Figura 2 - Parâmetros de fluorescência de clorofila de acordo com o dia em que a análise foi feita em DFFF 1500 umol $m^{-2} s^{-1}$. Tratamento controle (preto); Tratamento de estresse hídrico (branco) plantas reidratadas após período de déficit hídrico. a. $F_{\mathrm{v}} / F_{\mathrm{M}}-$ eficiência quântica máxima do PSII. b. $\mathrm{qP}$-dissipação fotoquímica. $\boldsymbol{c}$. ETR - taxa de transporte de elétrons. d. NPQ dissipação não fotoquímica. A seta indica a reidratação. Valores referentes à média e erro padrão $(n=4)$. * Indica diferença significativa de $p<0.05$.

Our studies showed that $C$. langsdorffii has high plasticity index (PI) of $g_{\mathrm{s}}$, according to the drought $(0.775 \pm 0.13 \mathrm{SD})$ and rehydration $(0.533 \pm 0.23 \mathrm{SD})$ analyses. However, this variable was not showing significant differences between drought and rehydration $(p<0.05)$ (Table 2).

\section{DISCUSSION}

The decrease in RWC values during water stress is consistent with the pattern of responses frequently observed in other studies that evaluated the physiological responses to water stress (Duan et al., 2005). Our results showed minimal RWC values under water stress. $C$. langsdorffii plants showed $15 \%$ decrease compared to control treatment. The decreases in RWC results in stomatal closure, which protects from future irreversible cell dehydration under progressive drought conditions (Luo et al., 2014).

The $g_{\mathrm{s}}$ remained lower even $96 \mathrm{~h}$ of rehydration. Gimenez et al. (2005) showed that $g_{\mathrm{s}}$ values may require several hours, even days, to recover and get close to similar non-stressed levels. The delays in $g_{\mathrm{s}}$ are possible chemical signals stimulated by irrigation suspension, as well as indicated that equilibrium through rehydration was not achieved.

The slow response of $g_{\mathrm{s}}$ is contrasted by the fast $\mathrm{RWC}$ recovery. The quick increase in RWC data indicated 
Table 1 - Maximum fluorescence of dark-adapted leaves $\left(F_{\mathrm{M}}\right)$, minimum fluorescence of dark-adapted leaves $\left(F_{0}\right)$ and effective quantum yield of PSII ( $\left.\Phi_{\mathrm{PSII}}\right)$ of $C$. langsdorffii submitted to Control and Water stress treatment with subsequent recovery.

Tabela 1 - Fluorescência máxima em folhas adaptadas ao escuro $\left(F_{\mathrm{M}}\right)$, fluorescência mínima de folhas adaptadas ao escuro $\left(F_{0}\right)$ e rendimento quântico efetivo do PSII $\left(\Phi_{\mathrm{PSII}}\right)$ de $\boldsymbol{C}$. langsdorffii submetidas aos tratamentos Controle e Estresse hídrico com posterior recuperação.

\begin{tabular}{|c|c|c|c|c|c|c|}
\hline & \multicolumn{2}{|c|}{$F_{0}$} & \multicolumn{2}{|c|}{$F_{\mathrm{M}}$} & \multicolumn{2}{|c|}{$\Phi_{\mathrm{PSH}}$} \\
\hline & Control & Water stress & Control & Water stress & Control & Water stress \\
\hline Drought & $151 \pm 9.4$ & $142 \pm 14.1$ & $673 \pm 35.5$ & $658 \pm 85.6$ & $0.088 \pm 0.03$ & $0.095 \pm 0.02$ \\
\hline $24 \mathrm{~h}$ & $188 \pm 4.9^{*}$ & $147 \pm 15.0 *$ & $897 \pm 49.2$ & $745 \pm 72.9$ & $0.073 \pm 0.02$ & $0.079 \pm 0.02$ \\
\hline $48 \mathrm{~h}$ & $192 \pm 8.6$ & $194 \pm 6.1$ & $782 \pm 43.3$ & $769 \pm 37.4$ & $0.057 \pm 0.01 *$ & $0.097 \pm 0.03 *$ \\
\hline $96 \mathrm{~h}$ & $155 \pm 12.7$ & $152 \pm 10.5$ & $614 \pm 73.2$ & $631 \pm 58.6$ & $0.102 \pm 0.03$ & $0.090 \pm 0.01$ \\
\hline
\end{tabular}

Values are the mean $\pm \operatorname{SE}(n=4)$ of the variables evaluated. $*$ Indicate significant differences at $p<0.05$.

tissue rehydrated due to mechanism of stomatal control represented by low $g_{\mathrm{s}}$ values, even after rehydration. Thus, lower $g_{\mathrm{s}}$ values indicate the presence of a mechanism used to control the water lost by $C$. langsdorffii to overcome water deficit. The plant can modulate $g_{\mathrm{s}}$ rates through stomatal aperture regulation depending on the need for water balance (Carvalho, 2008; Zhang et al., 2010; Kudoyarova et al., 2013; Hanachi et al., 2014).

The $g_{\mathrm{s}}$ variable presented the higher PI according to analyses of the drought and $96 \mathrm{~h}$ rehydrated (Table 2 ). The high plastic responses to heterogeneous environments (i.e., phenotypic plasticity) allow the species to increase their ecological breadth as well as increase in available resources (Liu et al., 2015).

Table 2 - Plasticity indices (PIs) of different variables according to the water availability in the Water stress treatment. Relative water content (RWC); Stomatal conductance $\left(g_{\mathrm{s}}\right)$; Maximum quantum efficiency of PSII $\left(F_{\mathrm{V}} / F_{\mathrm{M}}\right)$; Electron transport rate (ETR); Photochemical quenching (qP); Non-photochemical quenching (NPQ).

Tabela 2 - Índice de plasticidade (PIs) de diferentes variáveis de acordo com disponibilidade deágua no tratamento de Estresse hídrico. Conteúdo relativo de água (RWC); Condutância estomática $\left(g_{\mathrm{s}}\right)$; Eficiência quântica máxima do PSII $\left(F_{\mathrm{v}} / F_{\mathrm{M}}\right)$; Taxa de transporte de elétrons (ETR); Dissipação fotoquímica (qP); Dissipação não fotoquímica (NPQ).

\begin{tabular}{ccc}
\hline Variable & Drought & 96 h rehydrated \\
\hline RWC & $0.167 \pm 0.12$ & $0.061 \pm 0.04$ \\
$g_{\mathrm{s}}$ & $0.775 \pm 0.13$ & $0.533 \pm 0.23$ \\
$F_{\mathrm{V}} / F_{\mathrm{M}}$ & $0.052 \pm 0.03$ & $0.041 \pm 0.02$ \\
$\mathrm{ETR}$ & $0.319 \pm 0.14$ & $0.306 \pm 0.10$ \\
$\mathrm{qP}$ & $0.185 \pm 0.16$ & $0.190 \pm 0.15$ \\
$\mathrm{NPQ}$ & $0.392 \pm 0.21$ & $0.300 \pm 0.11$ \\
\hline
\end{tabular}

Revista Árvore. 2017;41(2):e410219
The observed $F_{\mathrm{V}} / F_{\mathrm{M}}$ showed no photoinhibition according to Baker (2008) and did not show significantly different between treatments. Cornic (2000) indicated that the instantaneous response of plants to quantum efficiency when they were rehydrated suggests that the photochemical and biochemical mechanisms were not damaged by water scarcity, even with the decreased $g_{\mathrm{s}}$. The $F_{\mathrm{v}} / F_{\mathrm{M}}$ is a common parameter and it is inversely proportional to the damages in the PSII reaction centres (Farquhar et al., 1989). Therefore, our results indicate that there was no damage to the PSII reaction centres, even when irrigation was suspended.

With different protection strategies to alleviate the damage caused by drought, the plants exhibit different responses in their photochemical apparatus (Cooper and Farrant, 2002). Water stress period imposed for C. langsdorffii was not enough to damage the photochemical responses even with rehydration. This study showed that the $F_{0}$ of rehydrated treatment increased, while the $F_{\mathrm{M}}$ value did not show significantly difference between treatments. The data indicate that the photosynthetic apparatus was not damaged and can recover within the relatively short time. This suggests that the proteins present were adequate to maintain normal photosynthetic metabolism for a considerable period subsequent to rehydration (Cooper and Farrant, 2002; Guo et al., 2016).

The photochemical performance increased $48 \mathrm{~h}$ of rehydration. The $\Phi_{\text {PSII }}$ provides the proportion of absorbed light actually used in PSII photochemistry. It can, therefore, be used to estimate the electron transport rate (ETR) through PSII, when the light absorbed by the leaf and the photosystems is known (Murchie and Lawson, 2013). Such result corroborates the data in the current study, which showed higher $\Phi_{\text {PSII }}$ values 
in the second day after rehydration in water stress treatment. The $\Phi_{\text {PSII }}$ is an indicator of real photochemical activity (Genty et al., 1989; Duan et al., 2005). So, the increased $\Phi_{\text {PSII }}$ may have resulted from the increased ETR, as well as from the increase in open reactions centres ( $\mathrm{qP})$, as shown in our results. This increase in photochemical activity during water stress can be a characteristic of drought tolerant plants, which could alleviate the effects of stress on photosynthetic machinery and improve their resilience (Rivas et al., 2016).

The ETR and qP showed significant differences between treatments 48 hours of rehydration, when the water deficit treatment showed higher values than control treatment. The increased ETR and qP indicate that the electron transport ability was optimized i.e. enhanced the capacity of the photosynthetic apparatus to maintain QA in the oxidized state (Zhao et al., 2007; Stefanov et al., 2016). This ability of electron transport optimization improves the light absorbed efficiency by PSII, which is used for QA reduction $\left(\Phi_{\mathrm{PSII}}\right)$ and accelerates the overall electron transport through PSII (Dobrikova et al., 2014; Stefanov et al., 2016). The ETR is a dynamic parameter and it may be a good indicator to estimate the light induction of the species' photosynthetic rate due to its great acclimation capability (Wong et al., 2012). It could be suggested that the increase of electron transport rate and the photochemical quenching in $C$. langsdorffii submitted to water stress is one of the reasons for the dry tolerance of the species to drought. Thus, these observations are associated with an efficient mechanism to cope with water stress.

NPQ increased in both control and stressed plants $48 \mathrm{~h}$ of rehydration with no difference between them, as well as ETR and qP. These patterns may be effective in preventing PSII over-excitation and the consequent chronic photosynthesis photoinhibition in $C$. langsdorffii. The higher $\Phi_{\mathrm{PSII}}$ in water stress group reinforces the idea that it was not necessary to increase the non-photochemical dissipation of absorbed light energy in the water stress group, since the absorbed light energy was sent to photochemical reactions (Einali et al., 2013).

These adjustment strategies of $C$. langsdorffii found in Cerrado physiognomies corroborate data by Veiga and Habermann (2013), who suggest that species in this ecosystem exhibit photoprotection performance under water stress. Thus, the capacity of making diurnal adjustments in photochemical and non-photochemical processes in order to overcome photoinhibitory threats would play a central role in the understanding of photosynthesis acclimation in seasonal environments like in Cerrado, regardless of the prevailing irradiance levels and degree of stomata closure (Franco and Lüttge, 2002). The recovery of the photochemical efficiency observed through chlorophyll fluorescence parameters is evidenced by the high resilience of the photosynthetic apparatus in the species under drought conditions (Maxwell and Johnson, 2000; Dongsansuk et al., 2013; Zong et al., 2014).

\section{CONCLUSION}

In summary we have presented that the species demonstrated photoprotection when it was exposed to water stress. $\Phi_{\text {PSII }}$, ETR and $\mathrm{qP}$ were higher in rehydrated plants submitted to water stress treatment than in the control treatment. Plants did not show heat dissipation similar to the NPQ values between the control and the water stress groups. The lower $g_{\mathrm{s}}$ values indicated the mechanism of the plant to control water loss and our study revealed higher plasticity of $g_{\mathrm{s}}$ subjected to water restriction and rehydration. Therefore, the rapid rehydration after the drought and the photochemical performance presented, allows the survival of $C$. langsdorffii in environments that present periods of water restriction as in Cerrado.

\section{ACKNOWLEDGMENT}

The authors thank the institution CAPES (Coordenação de Aperfeiçoamento de Pessoal de Nível Superior) and FAPESP (Fundação de Amparo à Pesquisa

do Estado de São Paulo - Proc. 2010/15585-6) for the financial support.

\section{REFERENCES}

Anjos L, Oliva MA, Kuki KN, Mielke MS, Ventrella MC, Galvão MF et al. Key leaf traits indicative of photosynthetic plasticity in tropical tree species. Trees. 2015;29:247-58.

Baker NR. Chlorophyll Fluorescence: A Probe of photosynthesis in vivo. Annual Review of Plant Physiology. 2008;59:89-113.

Barros FV, Goulart MF, Sá Telles SB, Lovato MB, Valladares F, Lemos-Filho JP. Phenotypic plasticity to light of two congeneric trees from contrasting 
habitats: Brazilian Atlantic Forest versus cerrado (savanna). Plant Biology. 2012;14:208-15.

Carvalho MHC. Drought stress and reactive oxygen species. Plant Signaling \& Behavior. 2008;3:156-65.

Carvalho PER. Espécies arbóreas brasileiras. Brasília, DF: Embrapa Informação Tecnológica; 2003.1039p.

Chaves MM, Pereira JS, Maroco J, Rodrigues ML, Ricardo CPP, Osório ML. et al. How plants cope with water stress in the field. Photosynthesis and growth. Annals of Botany. 2002;89:907-16.

Cooper K, Farrant JM. Recovery of the resurrection plant Craterostigma wilmsii from desiccation: protection versus repair. Journal of Experimental Botany. 2002;53(375):1805-13.

Cornic G. Drought stress inhibits photosynthesis by decreasing stomatal aperture-not by affecting ATP synthesis. Trends in Plant Sciences. 2000;5:187-8.

Dalmolin AC, Lobo FA, Vourlitis G, Silva PR, Dalmagro HJ, Antunes Jr MZ. et al. Is the dry season an important driver of phenology and growth for two Brazilian savanna tree species with contrasting leaf habits? Plant Ecology. 2015;216:407-17.

Dobrikova AG, Vladkova RS, Rashkov GD, Todinova SJ, Krumova SB, Apostolova EL. Effects of exogenous 24-epibrassinolide on the photosynthetic membranes under non-stress conditions. Plant Physiology and Biochemistry. 2014;80:75-82.

Dongsansuk A, Lütz C, Neuner G. Effects of temperature and irradiance on quantum yield of PSII photochemistry and xanthophyll cycle in a tropical and a temperate species. Photosynthetica. 2013;51:13-21.

Duan B, Lu Y, Yin C, Junttila O, Chunyang L. Physiological responses to drought and shade in two contrasting Picea asperata populations. Physiologia Plantarum. 2005;124:476-84.

Einali A, Shariati M, Sato F. Cyclic electron transport around photosystem I and its relationship to non-photochemical quenching in the unicellular green alga Dunaliella salina under nitrogen deficiency. Journal of Plant Research. 2013;126:179-86.

Elsheery NI, Cao EKF. Gas exchange, chlorophyll fluorescence, and osmotic adjustment in two mango cultivars under drought stress. Acta Physiologiae Plantarum. 2008;30:769-77.

Farquhar GD, Wong SC, Evans JR, Hubick KT. Photosynthesis and gas exchange. In: Jones HG, Flowers TJ, Jones MB, editors. Plants under stress. Warwick: Institute of Horticultural Research, 1989. 268p.

Ferreira WN, Lacerda CF, Costa RC, Medeiros Filho S. Effect of water stress on seedling growth in two species with different abundances: the importance of Stress Resistance Syndrome in seasonally dry tropical forest. Acta Botanica Brasilica. 2015;29:375-82.

Franco AC, Lüttge U. Midday depression in savanna trees: coordinated adjustments in photochemical efficiency, photorespiration, $\mathrm{CO}_{2}$ assimilation and water use efficiency. Oecologia. 2002;131:356-65.

Gaspar T, Franck T, Bisbis B, Kevers C, Jouve L, Hausman JF et al. Concepts in plant stress physiology. Application to plant tissue cultures. Plant Growth Regulation. 2002;37:263-85.

Genty B, Briantais JM, Baker NR. The relationship between the quantum yield of photosynthetic electron transport and quenching of chlorophyll fluorescence. Biochimica et Biophysica Acta. 1989;990:87-92.

Gimenez C, Gallardo M, Thompson RB. Plant - water relations. Encyclopedia of Soils in the Environment. 2005. p.231-8.

Giorgi F, Lionello P. Climate change projections for the Mediterranean region. Global and Planetary Change. 2008;63:90-104.

Guo YY, Yu HY, Kong DS, Yan F, Zhang YJ. Effects of drought stress on growth and chlorophyll fluorescence of Lycium ruthenicum Murr. seedling. Photosynthetica. 2016;54:1-8.

Hanachi S, van Labeke MC, Mehouachi T. Application of chlorophyll fluorescence to screen 
eggplant (Solanum melongena L.) cultivars for salt tolerance. Photosynthetica. 2014;52:57-62.

Intergovernmental Panel on Climate Change IPCC. Climate Change. Synthesis Report. Cambridge: Cambridge University Press; 2007. 1330 p.

Kudoyarova GR, Kholodova P, Veselov DS. Current state of the problem of water relations in plants under water deficit. Russian Journal of Plant Physiology. 2013;60:165-75.

Liu S, Luo Y, Yang R, He C, Cheng Q, Tao J et al. High resource-capture and-use efficiency, and effective antioxidant protection contribute to the invasiveness of Alnus formosana plants. Plant Physiology and Biochemistry. 2015;96:436-47.

LPWG - The Legume Phylogeny Working Group. A new subfamily classification of the Leguminosae based on a taxonomically comprehensive phylogeny. Taxon. 2017; 66:44-77.

Luo Y, Zhao X, Qu H, Zuo X, Wang S, Huang W et al. Photosynthetic performance and growth traits in Pennisetum centrasiaticum exposed to drought and rewatering under different soil nutrient regimes. Acta Physiologiae Plantarum. 2014;36:381-8.

Martins K, Kimura RK, Francisconi AF, Gezan S, Kainer K, Chritianini AV. The role of very small fragments in conserving genetic diversity of a common tree in a hyper fragmented Brazilian Atlantic forest landscape. Conservation Genetics. 2015;17:509-20.

Maxwell K, Johnson GN. Chlorophyll fluorescence - a practical guide. Journal of Experimental Botany. 2000;51:659-68.

Melo Júnior JCF, Bona C, Ceccantini G. Anatomia foliar de Copaifera langsdorffii Desf. (Leguminosae): interpretações ecológicas em diferentes condições edáficas de Cerrado. Biotemas. 2012;25:29-36.

Meng LL, Song JF, Wen J, Zhang J, Wei JH. Effects of drought stress on fluorescence characteristics of photosystem II in leaves of Plectranthus scutellarioides. Photosynthetica. 2016;54:1-9.
Murchie EH, Lawson T. Chlorophyll fluorescence analysis: a guide to good practice and understanding some new applications. Journal of Experimental Botany. 2013;64:3983-98.

Pedroni F, Sanchez M, Santos AM. Fenologia da copaíba (Copaifera Langsdorffii Desf. Leguminosae, Caesalpinioideae) em uma floresta semidecídua no sudeste do Brasil. Brazilian Journal of Botany. 2002;25:183-94.

Rivas R, Falcão HM, Ribeiro RV, Machado EC, Pimentel C, Santos MG. Drought tolerance in cowpea species is driven by less sensitivity of leaf gas exchange to water deficit and rapid recovery of photosynthesis after rehydration. South African Journal of Botany. 2016;103:101-7.

Ronquim CC, Prado CHBA, Souza JD. Growth, photosynthesis and leaf water potential in young plants of Copaifera langsdorffii Desf. (Caesalpiniaceae) under contrasting irradiances. Brazilian Journal of Plant Physiology. 2009;21:197208.

Smart RE, Bingham GE. Rapid estimates of relative water content. Plant Physiology. 1974;53:258-60.

Smirnoff N. Tansley Review No. 52 The role of active oxygen in the response of plants to water deficit and desiccation. New Phytologist. 1993;125:27-58.

Stefanov M, Yotsova E, Rashkov G, Ivanova K, Markovska Y, Apostolova EL. Effects of salinity on the photosynthetic apparatus of two Paulownia lines. Plant Physiology and Biochemistry. 2016;101:54-9.

Valladares F, Martinez-Ferri E, Balaguer L, PerezCorona E, Manrique E. Low leaf-level response to light and nutrients in Mediterranean evergreen oaks: a conservative resource-used strategy? New Phytologist. 2000;148:79-91.

Varone L, Ribas-Carbo M, Carnoda C, Gallé A, Medrano H, Gratani L et al. Stomatal and nonstomatal limitations to photosynthesis in seedlings and saplings of Mediterranean species pre-conditioned and aged in nurseries: Different response to water stress. Environmental and Experimental Botany. 2012;75:235-47. 
Vaz M, Pereira JS, Gazarini LC, David TS, David JS, Rodrigues A et al. Drought-induced photosynthetic inhibition and autumn recovery in two Mediterranean oak species (Quercus ilex and Quercus suber). Tree Physiology. 2010;30:946-56.

Veiga EB, Habermann G. Instantaneously measured traits may detect non-plastic ecophysiological performances in response to drought, explaining distributions of Styrax species in the Cerrado. Trees. 2013;27:1737-45.

Wong SL, Chen CW, Huang HW, Weng JH. Using combined measurements for comparison of light induction of stomatal conductance, electron transport rate and $\mathrm{CO}_{2}$ fixation in woody and fern species adapted to different light regimes. Tree Physiology. 2012;32:535-44.
Wu X, Bao W. Leaf growth, gas exchange and chlorophyll fluorescence parameters in response to different water deficits in in wheat cultivars. Plant Production Science. 2011;14:254-9.

Zhang YH, Chen LJ, He JL, Qian LS, Wu LQ, Wang RF. Characteristics of chlorophyll fluorescence and antioxidative system in super-hybrid rice and its parental cultivars under chilling stress. Biologia Plantarum. 2010;54:164-8.

Zhao LY, Deng XP, Shan L. Effects of altered water condition on some chlorophyll fluorescence parameters of flag leaves of winter wheat. Chinese Journal of EcoAgriculture. 2007;15:63-6.

Zong YZ, Wang WF, Xue QW, Shangguan ZP. Interactive effects of elevated $\mathrm{CO} 2$ and drought on photosynthetic capacity and PSII performance in maize. Photosynthetica. 2014;52:63-70. 